\title{
Performance of Credit Obligations by Business Entities during the COVID-19 Pandemic
}

\footnotetext{
Submitted 06/06/20, 1st revision 11/07/20, 2nd revision 19/08/20, accepted 15/09/20

Tatyana A. Skvortsova ${ }^{1}$, Gennady S. Pratsko ${ }^{2}$, Tatyana A. Mosienko ${ }^{3}$, Yana I. Kurinova ${ }^{4}$, Aelita Y. Ulezko ${ }^{5}$

Abstract:

Purpose: The purpose is to establish an economic and legal analysis of the problems, arising from performing credit obligations by business entities during the COVID-19 pandemic.

Design/Methodology/Approach: The authors studied the concept and substance of lending and credit relations, analyzed the lending statistics of business subjects in the Russian Federation, considering the mechanisms of support for business borrowers stipulated by Russian legislation with the use of the national scientific methods of knowledge (analysis, aggregation, induction, deduction, etc.) and special scientific methods (system-structural, comparative-legal).

Findings: As a result, the authors have concluded on the need to increase lending to the business sector in the Russian Federation, since in this case lending relations will be an incentive for the development of the country's economy. It is also necessary to improve the effectiveness of measures to support borrowers - business entities affected by the introduction of a high-readiness and self-isolation regime.
}

Practical Implications: The authors propose legal mechanisms to support borrowers business entities of industries most affected by the introduction of a restrictions and selfisolation regime in connection with the threat of the spread of new coronavirus infection COVID-19; in particular, they propose to formalize banks`and other credit institutions obligations regulatory to perform preferential lending and to grant deferrals on loans (borrowings) of this entrepreneurs` category.

Originality/Value: The government's policy to support borrowers doing business in the sectors most affected by the restrictions imposed on their operations due to the threat of a new coronavirus infection COVID-19 does have a significant impact on the ability of borrowers to meet their obligations under loan agreements to banks and other credit institutions.

Keywords: Business entities, SMEs, lending, credit relations, credit and borrowings.

JEL codes: G21, E51, K12.

Paper type : Research article.

${ }^{1}$ Corresponding author, Rostov State University of Economics, Department of civil law,

Rostov State Transport University, Department of civil law and procedure,

tas242@yandex.ru

${ }^{2}$ Don State Technical University, Department of commercial and business law, Rostov State

Transport University, Department of civil law and procedure, gpip@ rgups.ru

${ }^{3}$ Rostov State University of Economics, Department of civil law, mosienko-5858@mail.ru

${ }^{4}$ Rostov State University of Economics, Department of innovation management and entrepreneurship,kafedra37@bk.ru

${ }^{5}$ Rostov State University of Economics, Department of civil law, litas2011@yandex.ru 


\section{Introduction}

In a market economy, the institution of lending to business is of great importance. The size of shareholders' equity that makes up the organization's own funds at the start of entrepreneurial activity is very small (Skvortsova, Kolesnikov, Mosienko, Romanenko, 2017). Therefore, many organizations are forced to raise credit funds when doing business. The availability of credit resources for entrepreneurs is one of the priorities of the economy.

At the same time, the level of lending to business entities in the Russian Federation is very low. The reasons for the current situation lie in the lack of reliable borrowers, non-compliance of the borrower with the established conditions, lack of collateral for loans, non-transparency of business activity, and other factors. The limited supply of credit resources for business entities in the Russian Federation and the lack of a competitive market for lending services contribute to maintaining high interest rates (Ruchkina, 2014).

Due to the very high interest rate, entrepreneurs are often unable to repay their loan. The problem of non-payment of loans is particularly acute at a time when the Russian economy is suffering from the introduction of measures to combat a new coronavirus infection (Grima et al., 2020; Khan et al., 2020). Many entities were unable to operate due to the introduction of prohibitions and restrictions, which directly affected their solvency and payments on previously received loans.

This raises problems like proper performance of obligations under loan agreements. However, in order to ensure and maintain the stability of civil turnover, obligations must be properly fulfilled (Skvortsova et al., 2020). Therefore, there is a need for legislative consolidation and implementation of measures to support affected borrowers (Skvortsova, 2020).

\section{Concept and Substance of Lending and Credit Relations}

Credit relations form an integral part of any economic system. Their existence is due to the existence of temporarily free replacement property assets (goods, cash and non-cash funds, etc.) for some entities and the unmet need for them at the same time for other subjects of civil law. Credit relations make it possible to ensure a balanced economic development of the society through the distribution of "non-performing" property benefits to those in need of them and the return movement of similar objects to the person providing the loan (Mikrykov and Mikrykova, 2014).

The economic substance of lending relationships lies in lending money, i.e. providing money that is now needed in exchange for the promise of money in the future. The loan is generally described as a cash loan and a sale and purchase transaction. According to Zheronkin and Kaganova (2020), "the last is the transaction`s value without participation of a loan, while the first fills the" value 
vacuum "created by the receipt of benefits without immediate payment of spent resources. At the same time, it is obvious that the credit equivalent of the value of benefits is also money ".

There are different approaches to determining the economic substance of lending in the economic literature. We are closer to the theory of credit as a form of loan capital movement. This form is the provision of money for temporary possession and use, on conditions of return, urgency and payment (Trachtenberg, 1962).

According to the researchers, from the position of financial intermediary, the banking system is an important link in the national financial system, having a significant impact on the economy as a whole, since it provides the financial resources that companies need to expand and grow. Bank credit has a special place in the financial policy of economic agents, representing one of the most commonly used means of financing their current and/or investment activity (Urakova and Nutfulloev, 2020).

It should be noted that, like any external source of financing, bank loan has a number of disadvantages:

- it is issued at the discretion of the credit institution; therefore, is not available to all economic entities;

- obtaining a loan is not an easy procedure;

- often to obtain a loan it is necessary to provide security for its repayment, such as pledge, surety, etc.;

- the receipt of a bank loan as a source of financing may be related to certain restrictions on the firm's activity, for example, the need for its targeted use;

- in certain circumstances the bank may demand early repayment of the loan, may change the amount of interest (if the loan is received in currency), etc. All of it creates an additional risk for the business.

At the same time, lending is an important driver for business development. Lending has a positive effect both on the operations of the bank itself and on the activity of the company, which is financed by credit funds. For example, the business has new opportunities to expand, upgrade, etc. Thus, credit relations are caused by the transfer of money for temporary use on conditions of return, urgency, material security and for a fee in the form of interest. Such social relations are subject to legal regulation through certain civil law mechanisms.

The mechanism of legal regulation is a process of regulating social relations. Such rationalization or regulatory and organizational impact is achieved through various legal means that are interrelated and systemically united with each other and form various institutional entities (Epifanova et al., 2015). 
In the process of settling credit relations, the rules of law give rise to credit binding legal relations (credit obligations), which constitute legal relations, by virtue of which one party undertakes to transfer the other money and the other party undertakes to return the same amount of money, as well as to pay interest and other payments related to the provision of the loan.

According to scientists, credit obligations are a type of debt obligations: "In describing the current view of the legal nature of debt obligations, it should be indicated that they formalize economic relations, which are uniform in nature, on the transfer of money by one participant to another (also things under the loan agreement) with the condition of return of their equivalent and, as a rule, payment of remuneration, i.e. on the provision of a loan in the economic sense" (Sukhanov, 2011).

According to the authors of the commentary to the Civil Code of the Russian Federation, common rules applicable to almost all borrowings (in the form of loan rules that apply to other loan obligations pursuant to Clause 2 of Article 819, Part 1 of Article 822 and Clause 2 of Article 823 of the Civil Code of the Russian Federation) makes it possible to talk about the existence of a general category of debt and credit obligations, the most typical of which is the obligation from the loan agreement (Civil Code of the Russian Federation).

Indeed, Chapter 42 of the Civil Code of the Russian Federation distinguishes several legal forms mediating the credit and loan relations, uniform on the economic essence: loan agreement, credit agreement, commodity and commercial credit. Article 818 of the Civil Code of the Russian Federation also stipulates that a loan obligation may give rise not only to a loan or credit agreement, but also by agreement of the parties, a debt arising from any contract (sale, lease, etc.) or other grounds (damage, non-material enrichment, etc.) may be replaced by a loan obligation, i.e. novated in accordance with the requirements of Article 414 of the Civil Code. The courts assume that not only the main obligation, but also the additional obligation to pay the penalty (point 5 of information letter No. 103 of the Presidium of the Supreme Arbitration Court of the Russian Federation of 21 December 2005 "Review on the practice of arbitration courts in applying Article 414 of the Civil Code of the Russian Federation") may be new to the loan.

However, unlike other chapters governing various contracts (sale-purchase, lease, consecutive), there is no separate paragraph in Chapter 42 of the Civil Code of the Russian Federation containing general provisions applicable to all these relations, unless otherwise stipulated by special rules for them.

This fact gave rise to a scientific dispute over the ratio of these types of debt relations, and gave scientists a reason to consider the loan and credit as independent and balanced categories. Thus, S.K. Solomin considers the classification of the credit agreement as a type of loan, based on the norm of Point 2 of Article 819 of the Civil 
Code of the Russian Federation, as a mistake from one scientific work to another without any reasonable justification (Solomin, 2009).

The Model Rules of European Private Law provide a slightly different approach to a debt design: A loan agreement is an agreement by which one party, the lender, is required to provide a loan to the other party, the borrower, for a specified or indefinite period (the lending period) by providing the borrower with any monetary amount or lending its bank account, and the borrower is obligated to repay the loan received, regardless of whether the borrower is obligated to pay interest or other remuneration.

Thus, in European legislation the concept of a loan agreement is equal to that of a credit agreement, and in Russian law the legal substance of the loan agreement and the credit agreement differ, despite the fact that the contracts belong to the same group and credit is a type of loan, as we have shown in the previous paragraph of this work.

We could include a credit agreement in a group of agreements aimed at granting a deferral of the return of the same amount of property of the same kind and quality or a deferral of payment. Such group of contracts is made by agreements of loan, credit, bank deposit and the bank account (the contract of the bank account unites a loan and the obligation of rendering specific banking services). The economic and legal objectives of these contracts are to grant a deferral of the consideration of the equivalent consideration. There is no other purpose for the parties concluding a contract under which one party transfers property to the other party with the condition that the same amount of property of the same kind and quality is returned.

So, debt and credit obligations with a target focus are included in the same group with bank account and bank deposit agreements. However, despite the overall purpose of these obligations, it is necessary to point out their differences. For example, Deryuga (2014) correctly notes that despite the fact that the nature of the relations under the bank account agreement is similar to the relations of the loan agreement of money provided on demand: the bank is a debtor and the client is a creditor of the bank, such analogy with the loan agreement is acceptable only from the point of view that in these types of legal relations we see a binding legal relationship. According to the bank account agreement, in addition to the bank's obligation to return funds to the client, it is obligated to fulfill other orders of the client, which distinguishes it from debt obligations.

In our opinion, a special group of debt and credit obligations should be singled out. Loans and credits are binding relationships whereby one party transfers money to the other (fungible things) and the other party undertakes to return the same amount of money (things of the same kind and quality). These obligations have common features and mediate the provision of property determined by fungible things to the borrower, subject to the return of property similar to that provided. Based on this, we 
believe that it would be advisable to draw on the European experience in the legal regulation of debt obligations, which is included in the Model Rules of European Private Law.

\section{Statistics on the Receipt and Repayment of Loans by Business Rntities}

We will analyze the statistical data of lending to business entities according to the data of the Central Bank of the Russian Federation in the period before and after the introduction of restrictions due to the threat of COVID-19.

Figure 1. Number of legal entities and individual entrepreneurs received a loan (CBR, 2020)

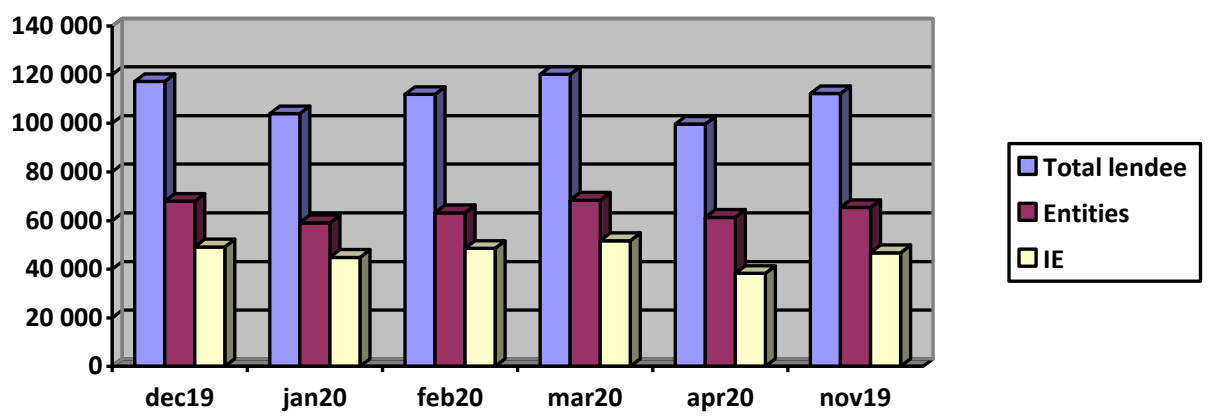

Source: Own study.

Based on the data presented, it can be concluded that the number of monthly loans issued to business entities prior to the introduction of restrictions due to the spread of coronavirus infection fluctuated slightly, with an average of about 110,000 per month. At the same time, the number of legal entities that received bank loans exceeded the number of individual entrepreneurs that received such loans. Statistics changed during the period of restrictions. We see a slight decrease in lending in April 2020, which is due to the introduction of a self-isolation regime in Russia and the ban on doing business in various spheres.

Now let's look at the data on debt on loans of business entities. Figure 2 a shows the number of resident legal entities and individual entrepreneurs in arrears and Figure $2 \mathrm{~b}$ shows the number of such entities in arrears.

Figures $2 \mathrm{a}$ and $2 \mathrm{~b}$ show that an average of 320,000 business entities have debt on loans, of which 47,000 have overdue debt. The number of legal entities with such debt approximates the number of individual entrepreneurs. Thus, if we compare the number of loans issued to business entities and the number of debtors, we can conclude that the total number of debtors of business entities, including those that have lost debt, is very small. The number of business entities with debt during the 
period when restrictive measures were introduced in connection with the pandemic has also not increased significantly. At the same time, the number of entities with overdue debts has decreased even slightly. In our opinion, this is due to the fact that the Government of the Russian Federation has implemented measures to support borrowers during the period of the recession. The statistics on the debt of SMEs as a whole reflect general trends for all business entities.

Figure 2a: Number of legal entities and individual entrepreneurs with debt on loans (including overdue loans) (CBR, 2020)

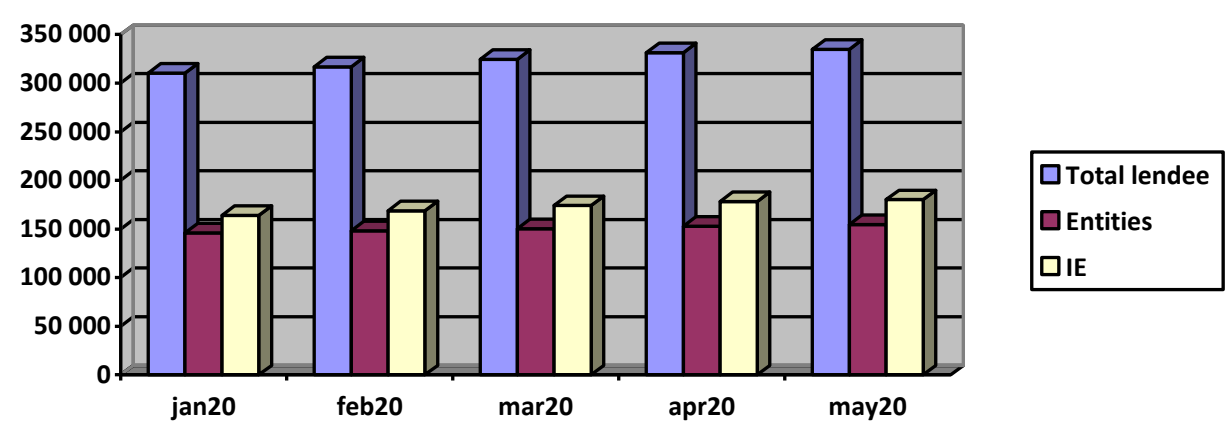

Source: Own study.

Figure 2b: Number of legal entities and individual entrepreneurs with overdue debts (CBR, 2020)

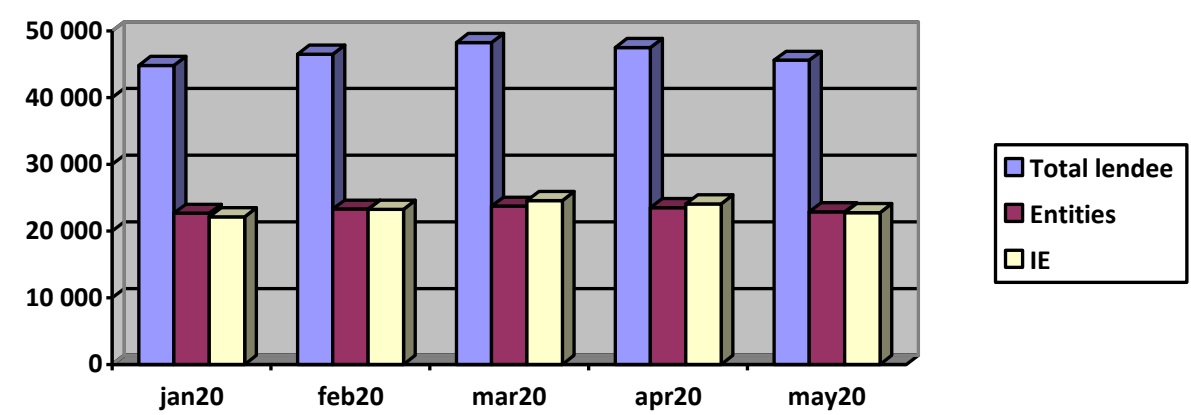

Source: Own study.

Figure 3a shows the number of small and medium-sized enterprises with debt on loans (including overdue loans), and Figure $3 \mathrm{a}$ shows the number of small and medium-sized enterprises with overdue debt. Based on the analysis of Figures 3a and $3 \mathrm{~b}$, it should be noted that in the segment of small and medium-sized enterprises there are significantly more debtors among individuals - individual entrepreneurs. Individual entrepreneurs also have larger amounts of overdue debt. In this regard, we believe that the state should pay special attention to this category of debtors and 
develop additional measures to attract individual entrepreneurs - small and mediumsized businesses in the period of the recession.

Figure 3a: Number of legal entities and individual entrepreneurs - SMEs with credit debt (CBR, 2020)

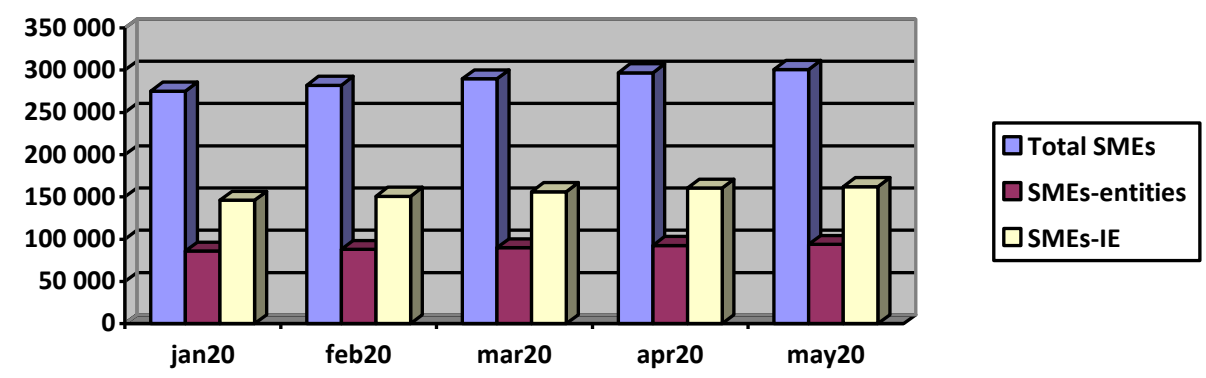

Source: Own study.

Figure 3b: Number of legal entities and individual entrepreneurs - SMEs with overdue credit debts (CBR, 2020)

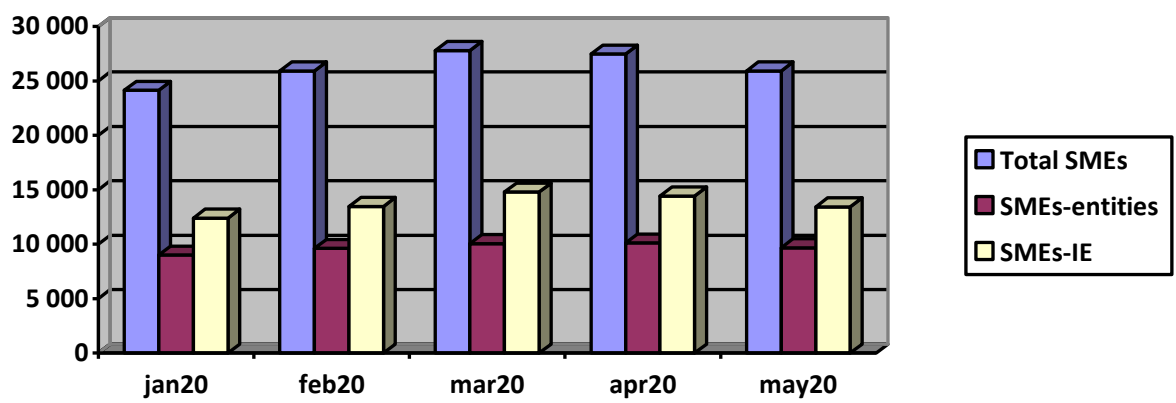

Source: Own study.

\section{Measures to Support Borrowers}

In order to ensure the normal development of economic relations, to prevent the nonpayment of loans by business entities: individual entrepreneurs and legal entities, it is necessary to provide legal support with specific measures of state financial policy to prevent the insolvency of entrepreneurs.

Federal Law No. 01.04.2020 of 98-FL On Amendments to Certain Legislative Acts of the Russian Federation on the Prevention and Elimination of Emergencies has already legalized a number of measures to support business entities that have worked in the industries most affected by the spread of new coronavirus infection. This list is established by The Government Resolution No. 434 of 03.04.2020 (ed. 26.06.2020) 
"On the Approval of the List of Sectors of the Russian Economies Most Affected by the Deterioration of the Situation as a Result of the Spread of New Coronavirus Infection." To date, it includes 12 areas of economic activity:

1. Transport activity;

2. Culture, leisure and entertainment;

3. Sports and sports;

4. Activity of travel agencies and other organizations providing tourism services;

5. Hotel business;

6. Public catering;

7. Activity of supplementary education organizations and non-state educational institutions;

8. Conference and exhibition activities;

9. Activities related to the provision of household services to the public (repair, washing, dry cleaning, hair and beauty salons);

10. Healthcare activities;

11. Retail trade in non-food products;

12. Mass media and production of printed materials.

Among the measures to support these areas of entrepreneurial activity, one should emphasize the possibility of preferential lending for the payment of salaries to employees of affected enterprises. However, it should be noted that banks are not obliged, but only entitled to provide such loans. In practice, credit institutions often deny such concessionary lending.

The Bank of Russia provides credit institutions with an opportunity not to worsen the assessment of the quality of debt servicing by 30 September 2020, regardless of the assessment of the borrower's financial position, on loans from organizations of the most affected industries restructured in connection with the recession. The Bank of Russia also allows credit institutions to make a decision by 30 September 2020 not to degrade the financial position assessment of the borrower for the purposes of creating provisions for losses, if the financial position of the borrower has deteriorated after 1 March 2020 and is caused by the spread of the pandemic.

Federal Law No. 106-FL "On Amendments to the Federal Law" On the Central Bank of the Russian Federation entered into force on 3 April 2020 (Bank of Russia) "and separate acts of the Russian Federation regarding features of change of conditions of the credit agreement, loan agreement" which provided an opportunity for citizens and businessmen to receive a delay of payments on the credits and loans for a period of up to half a year in case they suffered from decline in income in connection with a coronavirus pandemic (so-called credit vacation).

Individual borrowers may request the creditor to reduce the amount of payments during the grace period. This requires that the following conditions be met at the same time: 
- the size of the credit does not exceed the maximum sum determined by the Government of the Russian Federation (in particular, for consumer loans (credits) on which borrowers are individual entrepreneurs, - 300 thousand rubles);

- the borrower's income decreased by $30 \%$ or more for the month preceding the month of circulation compared to the average monthly income for 2019 . The method of calculating the average monthly income was approved by the Government of the Russian Federation;

- at the time of the credit vacation request, mortgage vacation is not applied to the credit agreement (loan agreement).

Borrowers may apply for credit holidays until 30 September 2020, but the Government of the Russian Federation may extend this period if necessary. Thus, mechanisms of support of borrowers -individual entrepreneurs do exist, but only on the personal credits (loans) and limited to the total amount of 300 thousand rubles. No credit holidays are stipulated for loans related to individuals entrepreneurial activity. Measures introduced by the state to support borrowers in relations with banks and other creditors mainly concern individuals who are not entrepreneurs. For business entities, however, such measures do not work fully in practice.

\section{Results}

Thus, the analysis of the lending market shows the need to increase lending to the entrepreneurial sector in the Russian Federation, since in this case lending relations will be an incentive for the development of the country's economy. In the area of legal regulation, we believe that it is possible to borrow European experience in regulating debt and credit obligations, which is included in the Model Rules of European Private Law.

For the purpose of ensuring effective support from the state to the business, including, subjects of small and medium business, victimized from introduction of high alert and self-isolation in connection with threat of spread of COVID-19, introduction of measures for granting delays by credit institutions on payments of the credits (loans) is necessary. At the same time, it is necessary to adopt legislative amendments obliging banks and other credit institutions to perform preferential lending and to grant deferrals on loans (borrowings) to business entities.

\section{Conclusions and Some Policy Implications}

In this article, the authors studied the concept and substance of lending and credit legal relations, analyzed the lending statistics of the subjects of entrepreneurship in the Russian Federation, and considered the mechanisms for supporting borrowersentrepreneurs stipulated by Russian legislation, using the public-interest formallogical methods of knowledge (analysis, aggregation, induction, deduction, etc.), as well as special scientific methods (system-structural, comparative-legal). 
The data analysis shows that in order to maintain the stability of the credit system of the country and to ensure the possibility of performing obligations under credit agreements by business entities during the period of the recession, it is necessary to implement the state policy on the sub-loan of borrowers. The normal functioning of the credit market and the economy as a whole depends on the creation of an effective regulatory and legal framework to support entrepreneurs operating in industries that have suffered the most due to the introduction of restrictions and selfisolation by the state.

\section{References:}

CBR. 2020. Statistical data of the Central Bank of the Russian Federation. Available at: https://cbr.ru/statistics/bank_sector/sors

Deryuga, N.N. 2014. Legal nature of the bank account agreement. Legal world, 8, 17-20.

Epifanova, T., Romanenko, N., Mosienko, T., Skvortsova, T., Kupchinskiy, A. 2015. Modernization of Institutional Environment of Entrepreneurship in Russia for Development of Innovation Initiative in Small Business Structures. European Research Studies Journal, 3(18), 137-148.

Grima, S., Dalli Gonzi, R., Thalassinos, I.E. 2020. The Impact of COVID-19 on Malta and its Economy and Sustainable Strategies. SSRN: https://ssrn.com/abstract=3644833.

Khan, S., Rabbani, R.M., Thalassinos, I.E., Atif, M. 2020. Corona Virus Pandemic Paving Ways to Next Generation of Learning and Teaching: Futuristic Cloud Based Educational Model. Available at SSRN: https://ssrn.com/abstract=3669832.

Mikrykov, V.A., Mikrykova, G.A. 2014. General provisions on borrowings. Legislation and economics, 10, 57-63.

Ruchkina, G.F. 2014. Improving the legal environment for financial support of small and medium-sized enterprises. Lawyer, 9, 29-32.

Skvortsova, T.A. 2020. Legal problems of the implementation of measures to support borrowers under loan agreements during the period of the recession. Science and education: economy and economics; business; Law and Administration, 6(121), 7175.

Skvortsova, T.A., Kolesnikov, Y.A., Mosienko, T.A., Romanenko, N.G. 2017. The formation of authorized capital in economic organizations. European Research Studies Journal, 3B(20), 369-378.

Skvortsova, T.A., Korolevskaya, O.I., Trunova, E.V., Kirilenko, V.S. 2020. Theoretical and Legal and Law Enforcement Aspects of the Liability for the Breach of Civil Obligations in Russia. Scientific and Technical Revolution: Yesterday, Today and Tomorrow. Lecture Notes in Networks and Systems, 129, 1046-1055.

Solomin, S.K. 2009. Bank credit: problems of theory and practice. Moscow, Yusticinform.

Sukhanov, E.A. 2011. Russian Civil Law: in 2 volumes. Moscow, Statute, 1208.

Trachtenberg, I.A. 1962. Cash circulation and credit under capitalization. Moscow, The publishing house of the USSR Academy of Sciences, 780.

Urakova, M.KH., Nutfulloev, T.G.U. 2020 Credit relations between banks and companies and their impact on the real economy. Scientific and educational achievements, 6(60), 13-15.

Zheronkin, S.A., Kaganova, D. 2020 To the methodology for analyzing economic credit relations and improvement of regulation of the Russian economy. Economics and Innovation Management, 1(12), 20-30. 